\title{
Poznámky $\mathrm{k}$ jurisdikčnímu a majetkovému sporu mezi Územním opatstvím sv. Martina na Panonské hoře a Trnavskou arcidiecézíi
}

Marián Sekerák

V jednom ze svých ekleziologických pojednání zdůraznil tehdejší prefekt Kongregace pro nauku víry, kardinál Joseph Ratzinger, že církev „se nesmí stát statickým společenstvím vedle sebe stojících místních církví, jež si v zásadě samy dostačují. Musí zůstat apoštolskou, jinak ře-

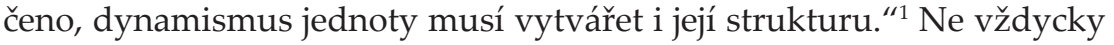
se ale tento ideál daří uplatňovat v praxi. Podobnou výjimkou, tedy narušením kýženého „dynamismu jednoty," je i několik desetiletí trvající spor mezi slovenskou Trnavskou arcidiecézí a mad’arským Územním opatstvím sv. Martina na Panonské hoře (lat. Abbatia Territorialis S. Martini in Monte Pannoniae, dále jen Pannonhalmské opatství), jež od konce 10. století spravuje řehole benediktinů.

Tento spor byl, alespoň se tak na první pohled jeví, uzavřen 13. listopadu 2015 dekretem Prot. N. 1742/1990 Kongregace pro instituty zasvěceného života a společnosti apoštolského života. ${ }^{2}$ Dekret nařizuje zrušit řeholní komunitu sv. Benedikta ve slovenském Komárně, čímž dává za pravdu současnému arcibiskupovi Trnavské arcidiecéze, mons. Jánu Oroschi, který je jediným a řádným ordinářem na území této arci-

Text byl zpracován v rámci Programu rozvoje vědných oblastí na Univerzitě Karlově v Praze (PRVOUK), P 17 Vědy o společnosti, politice a médiích ve výzvách doby, řešeném na Institutu politologických studií Fakulty sociálních věd Univerzity Karlovy. Autor děkuje za poskytnutí relevantní dokumentace Trnavskému arcibiskupství a Jeho Excelenci, mons. Imre Asztriku Várszegimu. Rovněž autor děkuje všem třem anonymním recenzentům i doc. Damiánu Němcovi za cenné připomínky k původní verzi článku, z nichž většina byla zapracována. Veškeré případné nedostatky jsou zodpovědností autora.

1 Joseph Ratzinger, Církev jako společenství, Praha: Zvon, 1995, s. 57. Více o Ratzingerově ekleziologii viz Ladislav SтRомс̌ек, Cirkev ako communio: Náčrt ekleziológie Josepha Ratzingera, Žilina: Inštitút Communio, n.o., 2010.

2 Tlačová KANCELÁria KBS, „,Vyhlásenie k zrušeniu Rádu sv. Benedikta v Komárne Svätou stolicou," https://www.tkkbs.sk/view.php?cisloclanku=20151214046 [zveřejněno 14. 12. 2015, cit. 18. 12. 2015]. 
diecéze, a vyvrací dosavadní argumentaci arciopata Pannonhalmského opatství a současně předsedajícího opata Mad’arské benediktinské kongregace, jímž je mons. Dr. Imre Asztrik Várszegi, O.S.B., titulární biskup z Culusi, jehož působnost jakožto ordináře platí na území Mad’arska, a který v oficiálním styku vystupuje i jako „nejvyšší představený Řádu svatého Benedikta se sídlem v Komárně, " tedy současně ve třech funkcích. Tato skutečnost znesnadňuje určení toho, zda je třeba podřízenost řeholního domu v Komárně považovat za podřízenost vyššímu řeholnímu představenému, anebo pannonhalmskému ordináři, i když dosavadní vystupování arciopata před Trnavskou arcidiecézí i Svatým stolcem, jakož i Konstituce Kongregace mad’arských benediktinů z roku $1995^{3}$ (viz níže) naznačují, že se jedná o jurisdikční podřízenost ordináři dlícímu na území cizího státu, což je vzhledem k apoštolským konstitucím ze 70. let minulého století i dekretu mons. Sokola z roku 1990, na jehož základě byl mons. Oroschem odebrán souhlas k působení řádu na území arcidiecéze, nepř́ípustné.

Byla to právě tato benediktinská komunita, kolem níž se celý problém odvíjel a vlastně doposud odvíjí, jelikož mons. Várszegi, O.S.B., svým dopisem ze dne 15. 12. 2015 vznesl vůči zmíněnému dekretu kongregace protest a přislíbil využít u Svatého stolce všechny možné opravné prostředky, které nabízí kanonické právo, včetně odkladu platnosti zmíněného dekretu.

V tomto dopisu žádá pannonhalmský arciopat odvolat dekret Prot. N. 1742/1990 ze dne 13. 11. 2015, jímž tato kongregace nařizuje zrušit komunitu v Komárně a dává za pravdu mons. Oroschi, přičemž se autor dopisu opírá o kán. 1734, § 1 CIC/1983. Svou žádost formuloval po konzultaci s benediktinským opatem-primasem Notkerem Wolfem z Říma. Dekret z listopadu 2015 podle arciopata Várszegiho nerespektuje Konstituci mad’arských benediktinů z r. 1995, podle níž je dům v Komárně závislý na Pannonhalmě, ale přistupuje k němu v rozporu s touto konstitucí jako k autonomnímu domu. Tento dekret podle arciopata navíc nerespektuje kán. 50 CIC/1983, podle kterého „,[p]řed vydáním rozhodnutí si představený získá nezbytné poznatky a důkazy a - pokud je to možné - vyslechne ty, jejichž práva mohou být porušena." Podle arciopata se dekret kongregace nezakládá na pravdě proto, že (1) dům v Komárně nezvětšuje př́tomnost benediktinů na Slovensku; (2) nepodporuje

3 V tomto př́padě se jedná o tu konstituci (singulár), ne ty konstituce (plurál): The Constitution of the Hungarian Benedictine Congregation. 
(v ital. orig. „,non favorisca“) pastorační péči o mad’arsky mluvící věřící; (3) benediktinská př́tomnost v Komárně byla pramenem nepochopení u místních církevních komunit. ${ }^{4}$

V podobném duchu se arciopat mons. Várszegi vyjadřuje i ve svém dopisu z 15. 1. 2016, jehož adresátem je Pietro kardinál Parolin, státní sekretář Svatého stolce. V něm vyjadřuje svůj šok a překvapení z dekretu kongregace z listopadu 2015 a žádá kardinála Parolina o podporu v této věci (odvolává se přitom na svůj dopis témuž adresátovi z 2. 2. 2015) v duchu právní zásady "audiatur et altera pars. ${ }^{\text {" } 5}$

Ačkoliv má historie tohoto sporu své historické kořeny, které budou částečně dále objasněny, jeho jádro se odvíjí zejména od dekretu tehdejšího ordináře Trnavské arcidiecéze, mons. Jána Sokola, z roku $1990 .{ }^{6}$ Cílem tohoto textu bude tedy stručně nastínit církevněprávní pozadí kauzy, její vývoj v čase a aktuální situaci na základě dostupných informací. Hned pro začátek je ale nutné zdůraznit, že přímé citace některých dokumentů, na něž se budu odvolávat, nejsou vzhledem $\mathrm{k}$ jejich důvěrné povaze možné. Na druhé straně čestně prohlašuji, že všechny níže uváděné faktografické informace jsou pravdivé a zakládají se na reálně existující dokumentaci.

\section{Dekret z ROKU 1990}

Po roce 1989 se církevní život v tehdejším Československu začal pomalu obnovovat. Součástí této obnovy byl i návrat řeholníků a řeholnic do diecézí a obnovení jejich aktivního duchovního působení. Ve zmíněném roce 1990, konkrétně 12. září, vydal mons. Sokol svůj dekret č. 3583/1990, jímž udělil svůj výslovný souhlas pro vstup Řádu sv. Benedikta (lidově benediktini) na území jemu svěřené arcidiecéze, a to v souladu s CIC/1983, kán. 609. Konkrétně pro benediktinský dům v pohraničním městě Komárno, který ještě před vznikem Českosloven-

4 Dopis mons. Várszegiho č. 5-13/2015 z 15. 12. 2015, jehož adresátem je mons. João Braz kardinál De Aviz, prefekt Kongregace pro instituty zasvěceného života a společnosti apoštolského života.

5 Dopis mons. Várszegiho (bez uvedení čísla) z 15. 1. 2016 adresovaný mons. Pietru kard. Parolinovi, státnímu sekretáři Svatého stolce.

6 Arcidiecéze nesla od prosince 1977 jméno „Trnavská arcidiecéze,“ od března 1995 „Bratislavsko-trnavská arcidiecéze“ a od února 2008 se jmenuje opět „Trnavská arcidiecéze." Od roku 2008 již Trnava není metropolitním sídlem. 
ské republiky patřil (společně s farností Trávnik a farností Diakovce) do majetků a jurisdikce Pannonhalmského opatství a byl, zcela v souladu s kanonickým právem, vyňat z jurisdikce obří Ostřihomské arcidiecéze. K těmto historickým souvislostem se ještě vrátím. Tento svůj souhlas ale mons. Sokol podmínil třemi podmínkami, které tehdejší opat Pannonhalmského opatství, András József Szennay, O.S.B. († 2012), akceptoval: Za prvé, řád sv. Benedikta měl u př́ležitosti obnovení řeholní komunity v Komárně vytvořit klášter sui iuris, jenž by byl nezávislý na Pannonhalmském opatství. Za druhé, tento klášter by se jakožto nezávislý klášter sui iuris stal součástí Mad’arské benediktinské kongregace. Za třetí, Řád sv. Benedikta měl zde vytvořit noviciát, jenž by byl základem pro vznik skutečné řeholní komunity, a to zcela podle ustanovení Kongregace pro instituty zasvěceného života a společnosti apoštolského života.

\section{2. „ODNĚTí SOUHLASU, “ NE ZRUŠENí KLÁŠTERA}

Tyto výše zmíněné podmínky nebyly podle současného trnavského arcibiskupa mons. Orosche splněny, tudíž rozhodl svým dekretem č. 8037/14 z 5. listopadu 2014 o "odnětí souhlasu“ s působením řádu na území Trnavské arcidiecéze. Arcibiskup nerozhodl o zrušení kláštera de iure, jak se mohlo na první pohled zdát, jelikož tak může učinit podle stanov nejvyšší představený po konzultaci s diecézním biskupem (srov. kán. 616, § 1 CIC/1983). Pouze konstatoval, že z pohledu arcidiecéze se tento řád stal na jejím teritoriu nežádoucím, tudíž nepovažoval za vhodné, aby tam vykonával jakoukoli činnost. Současně rozhodl o jeho vymazání ze seznamu církevních právnických osob patřících k území Trnavské arcidiecéze, tedy seznamu řeholních komunit působících na jejím teritoriu. Tento seznam je zveřejňován ve Schematismu Trnavské arcidiecéze.

Po realizaci tohoto kroku se ze strany pannonhalmského arciopata mons. Várszegiho, O.S.B., rozběhla nejenom oficiální intervenční aktivita u Svatého stolce, ${ }^{7}$ ale i silná mediální kampaň probíhající na Slovensku.

7 Dopis mons. Várszegiho č. 5-8/2014 z 10. 12. 2014, jehož adresátem je mons. José Rodríguez Carballo, O.F.M., sekretář Kongregace pro instituty zasvěceného života a společnosti apoštolského života, dopis mons. Várszegiho č. 5-13/2015 z 15. 12. 2015, jehož adresátem je mons. João Braz kardinál De Aviz, prefekt Kongregace pro instituty zasvěceného života a společnosti apoštolského života, dopis mons. Várszegiho (bez 
Obě měly za cíl přesvědčit veřejnost na Slovensku i autority v Římské kurii, že mons. Orosch vyhnal svévolně benediktiny z Komárna, a to pouze za účelem získání jejich majetku.

Jelikož celá kauza má širší souvislosti, není snad bez zajímavosti na okraj zmínit, že autorkou článku útočícího na současného trnavského arcibiskupa, který byl uveřejněn dne 28. 12. 2014 ve slovenském deníku SME s titulkem „Arcibiskup vyhání benediktiny: Vzali jim pozemky, zrušili účet," je Marie Vrabcová. ${ }^{8}$ Tedy tatáž autorka, která je podepsána pod knihou interview s bývalým arcibiskupem mons. Róbertem Bezákem, ${ }^{9}$ bezprostředním předchůdcem mons. Orosche, jehož kauza odnětí pastorační péče o Trnavskou arcidiecézi Benediktem XVI. je - jak známo - do dnešních dnů bolestivou záležitostí partikulární církve na Slovensku.

Vrat’me se ale zpátky $\mathrm{k}$ jádru věci, tedy $\mathrm{k}$ tématu řeholního domu $\mathrm{v}$ Komárně. Jedním z hlavních důvodi̊ odnětí souhlasu s pastoračním působením ze strany mons. Orosche bylo to, že se v předmětném klášteře od jeho založení nerozvíjel řádný řeholní život, což je fakt, který byl na základě svědectví faráře $\mathrm{v}$ Komárnu řádně doložen i sekretáři Kongregace pro instituty zasvěceného života a společnosti apoštolského života, jímž je mons. José Rodríguez Carballo, O.F.M., titulární arcibiskup Bellicastra. Neexistoval žádný řeholník z kláštera v Komárně, který by byl schopen předložit důkazy o životě tamní řeholní komunity.

Jedinou osobu, která vystupovala ve jménu tohoto řeholního domu, byl Dr. Juraj Szalay. Ten však není benediktinským řeholníkem, nýbrž laikem, ekonomem a statutárním zástupcem kláštera v konání před veřejnými orgány. Na něj se jako na řádného právního zástupce odvolával před Svatým stolcem i pannonhalmský arciopat mons. Várszegi, O.S.B. Nebyl to tedy žádný řeholník, nýbrž laik, kdo zastupoval klášter v konání před veřejnými orgány Slovenské republiky. Již v červenci 1996 velvyslanectví Slovenské republiky v Mad’arské republice v rámci diplomatické korespondence („Informace o průběhu návštěvy velvyslanců akreditovaných v Budapešti v Pannonhalmě, v benediktinském klášteře,

uvedení čísla) z 15. 1. 2016, jehož adresátem je mons. Pietro kardinál Parolin, státní sekretář Svatého stolce.

8 Marie VRABCovÁ, „Arcibiskup vyháňa benediktínov: Vzali im pozemky, zrušili účet,“ http://domov.sme.sk/c/7565093/arcibiskup-vyhana-benediktinov-vzali-im-pozemky-zrusili-ucet.html [zveřejněno 28. 12. 2014, cit. 22. 12. 2015].

9 Marie Vrabcová, Róbert Bezák: Vyznanie, Vozokany: Navi Graf, 2013. 
u př́ležitosti tisícého výročí jeho založení“) informovalo Ministerstvo zahraničních věcí SR o tom, že existoval předpoklad, že „Pannonhalma by mohla mít zájem prodat restituovanou budovu a získat a převést tak finanční prostředky pro své potřeby v Mad’arské republice. ${ }^{\text {"10 }}$

\section{Modus VIVENDI, APOŠTOLSKÉ KONSTITUCE A SAMOSTATNÁ SLOVENSKÁ CÍRKEVNí PROVINCIE}

Jak již bylo zmíněno výše, problém majetku řeholního domu v Komárně má širší historické souvislosti. Trnavská apoštolská administratura, právní předchůdkyně dnešní Trnavské arcidiecéze, byla zřízena 29 . května 1922, přičemž Svatý stolec převzal celé území Ostřihomské arcidiecéze nacházející se v Československu do své vlastní správy. V roce 1927 byl následně mezi Svatým stolcem a Československou republikou uzavřen modus vivendi, jenž vstoupil v platnost 2 . února 1928, tedy dnem zaslání reciproční nóty schvalující tuto mezinárodní smlouvu ze strany Státního sekretariátu Svatého stolce.

Pro Československo byl nejdůležitějším ustanovením smlouvy první článek, v němž se smluvní strany dohodly, že „žádná část Československé republiky nebude podřízena ordináŕi, jehož sídlo jest za hranicemi Československého státu a že rovněž žádná československá diecéze nebude přesahovat státních hranic. "11 Jak zdůrazňuje F. X. Halas, to se týkalo „zejména Slovenska (případně Podkarpatské Rusi), kde rozlehlá území spadala pod správu biskupství se sídlem v Mad’arsku (...), což působilo jako rušivý element pro poválečný status quo a ohrožovalo zásadní princip československé politiky, že hranice stanovené trianonskou dohodou jsou definitivní. "12 Jak známo, trianonská mírová smlouva, podepsaná 4. června 1920 s Mad’arskem jakožto jedním z právních nástupců ně-

10 Vel’vyslanectvo Slovenskej republiky, č. j. 3567/96, Budapešt, 29. 7. 1996, „Informácia o priebehu návštevy Vv. akreditovaných v Budapešti v Pannonhalme, v benediktínskom kláštore, pri príležitosti 1.000-eho (sic!) výročia jeho založenia - informácia politická č. 27."

11 „Modus vivendi inter Sanctam Sedem et Rempublicam Cecoslovachum,“ Acta Apostolicae Sedis 20, č. 3 (1928): 65, čl. I. Český text: František Bednářr, Sbírka zákonů a nařízení ve věcech náboženských a církevních v republice Československé, Praha: Husova čs. evangelická fakulta bohoslovecká v Praze, 1929, s. 552-553.

12 František Xaver Halas, Fenomén Vatikán: Idea, dějiny a současnost papežství. Diplomacie Svatého stolce. České země a Vatikán, 1. vydání, 1. dotisk, Brno: CDK, 2005, s. 556. 
kdejší habsburské monarchie, uznávala „,nezávislost a územní celistvost nástupnických států," $\mathrm{s}$ čímž "byly spojeny značné územní ztráty“:13 od Mad’arska bylo z bývalých Uher ve prospěch dalších nástupnických států odděleno celkem $70 \%$ území a $60 \%$ obyvatelstva.

Podle čl. 3 modu vivendi, „ř́ády a kongregace řeholní, jejichž domy jsou v Československu, nebudou podléhat představeným provinciálních domů týchž řádů a kongregací v cizině." ${ }^{14}$ Zasahování řeholního představeného z provinciálního domu nacházejícího se mimo území Československa (tedy dnešní Slovenské republiky nebo České republiky) do chodu a života řeholních domů na tomto území bylo touto smlouvou zapovězeno.

Samostatná slovenská církevní provincie vznikla až o několik desítek let později po přijetí modu vivendi, a to rozhodnutím papeže Pavla VI. 30. prosince 1977. Událo se tak na základě apoštolské konstituce Qui divino, která oddělila území Trnavské apoštolské administratury od Ostřihomské arcidiecéze, povýšila ji na stupeň diecéze a vyzvedla ji současně na úroveň metropolitního sídla, přičemž jí byly jako sufragánní podřízeny všechny tehdejší diecéze na území Slovenska (Banská Bystrica, Nitra, Košice, Spiš, Rožňava). ${ }^{15}$ Tentýž den svou další konstitucí Praescriptionum sacrosancti upravil Pavel VI. hranice slovenských diecézí. Papežský dokument zřizující samostatnou církevní provincii podrobně definoval jednotlivé územní celky; některé z nich se ale nacházely mimo území spravovaného biskupem sídlícím v Československé socialistické republice. Jednalo se o území tří farností diecéze Györ (Mad’arsko) a dvě již zmíněné farnosti benediktinského opatství v Pannonhalmě, ležící na území tehdejší Slovenské socialistické republiky. Ty byly připojeny k nově založené Trnavské arcidiecézi. ${ }^{16}$

Hlavní myšlenkou obou konstitucí bylo „vyjmutí obyvatel společné republiky Čechů a Slováků z vlivu mad’arských biskupů a rumunského biskupa, ale v první řadě Apoštolský stolec sledoval zájem povýšit

13 Zdeněk Veselý, Dějiny mezinárodních vztahů, Plzeň: Aleš Čeněk, 2007, s. 219.

14 „Modus vivendi inter Sanctam Sedem et Rempublicam Cechoslovaciæ," Acta Apostolicae Sedis 20, č. 3 (1928): 65, čl. III.

15 Viz Pavel VI., „Constitutiones Apostolicæ Qui divino,“ Acta Apostolicae Sedis 70, č. 5 (1978): 275-276.

16 „Item duæ paroeciæ ad Abbatiam S. Martini in Monte Pannoniæ pertinentes atque in finibus Rei publicæ Slovacæ exstantes ab ipsa Abbatia seiungatur atque archidioecesi Tyrnaviensi aggregentur.“ PAvel VI., „,Constitutiones Apostolicæ Praescriptionum sacrosancti,"Acta Apostolicae Sedis 70, č. 5 (1978): 274. 
partikulární církev na samostatnou jednotku, jež bude mít v čele vysvěceného arcibiskupa, správce církevního území. "17 I když se hranice slovenských arcidiecézí a diecézí latinského i byzantského obřadu časem měnily a vznikly dokonce i některé nové církevněprávní územní celky, ${ }^{18}$ nic se nezměnilo na tom, že konstituce Apoštolského stolce nebyly zrušeny a zásady modu vivendi z roku 1928 týkající se principu svrchovanosti jurisdikce ordinářù, ${ }^{19}$ jakož i fundamentální zásady II. vatikánského koncilu týkající se vztahu církve a státu, tj. zásady náboženské svobody, spolupráce, autonomie a nezávislosti církve ${ }^{20}$ byly implicitně uplatněny v dekretu mons. Sokola z roku 1990 a akceptovány tehdejším pannonhalmským opatem Szennayem.

Je fakt, že jedna ze smluvních stran této mezinárodní smlouvy (ČSR) již neexistuje. Ačkoliv na počátku třetího tisíciletí byly s nástupnickými státy (SR a ČR) dojednány ze strany Apoštolského stolce bilaterální smlouvy, výslovně tento modus vivendi nebyl formálně zrušen. Na druhé straně po roce 1989 smluvní strany tuto smlouvu mlčky zrušily, a to vzhledem k (1) někdejšímu prohlášení Svatého stolce po únoru 1948, že se necítí být smlouvou vázán, (2) jejímu faktickému vypovězení ze strany Československa vydáním zákona č. 218/1949 Sb. o hospodářském zabezpečení církví a náboženských společností, (3) politickým jednáním mezi katolickou církví a státem po tzv. sametové revoluci, kdy bylo konstatováno, že „dostatečnou právní základnou se jeví mezinárodní smlouvy a deklarace lidských a občanských práv a že není třeba se vracet k velmi

17 Renáta Jakubčová, Vznik a vývoj slovenských cirkevných provincií: Študijné texty konfesijného práva pre študentov právnickej fakulty, Banská Bystrica: Právnická fakulta Univerzity Mateja Bela v Banskej Bystrici, 2013, s. 93-94.

18 Apoštolskou konstitucí Pastorali quidem permoti Jana Pavla II. z 31. 3. 1995 byla Košická diecéze povýšena na arcidiecézi a zřízena byla druhá, východní slovenská církevní provincie; apoštolskou konstitucí Ecclesiales communitates Jana Pavla II. z 21. 2. 1997 byl zřízen Košický apoštolský exarchát; apoštolskou konstitucí Spiritali emolumento Benedikta XVI. z 30. 1. 2008 byla Prešovská řeckokatolická eparchie povýšena na archieparchii a metropolii sui iuris, přičemž bulou Complures saeculorum z 30. 1. 2008 vznikla Bratislavská řeckokatolická eparchie a bulou Qui successimus z téhož dne byl Košický apoštolský exarchát povýšen na eparchii; apoštolskou konstitucí Slovachiæ sacrorum Antistites Benedikta XVI. z 14. 2. 2008 byly zreorganizovány hranice diecézí latinského obřadu a zřízena metropolitní Bratislavská arcidiecéze a vưči ní sufragánní Žilinská diecéze.

19 Jediným řádným ordinářem tehdejší Trnavské arcidiecéze byl mons. Ján Sokol.

20 Podrobněji viz Damián NĚMEc, Konkordátní smlouvy Svatého stolce s postkomunistickými zeměmi (1990-2008), Bratislava: Ústav pre vzt’ahy štátu a cirkvi, 2010, s. 54-59, 89-95. 
rámcové a již překonané (obsoletní) smlouvě z dvacátých let. “21 Navíc je třeba zdůraznit, že v prosinci 1989 během jednání zástupců Svatého stolce a zástupců federální vlády byl modus vivendi shledán „překonaným na základě mezinárodněprávního úzu zvaného clausula rebus sic stantibus, a tudíž neúčinným. ${ }^{\text {22 }}$

Je sice pravda, že několik řeholních subjektů působících na území Slovenské republiky je podřízených provinčnímu vedení mimo tohoto území, ${ }^{23}$ na druhé straně, komárenský dům je třeba považovat za dům závislý, a to vzhledem $\mathrm{k}$ osobě svého nejvyššího představitele, pannonhalmského arciopata mons. Várszegiho, O.S.B., i ke Konstituci Kongregace mad’arských benediktinů z roku 1995 (viz níže). Pannonhalmský arciopat má jurisdikci výlučně na území svého opatství, jehož hranice nepresahuji do Trnavské arcidiecéze a vzhledem $\mathrm{k}$ platnosti apoštolských konstitucí ani přesahovat nemohou. Není tedy právně možné nárokovat si území ani jurisdikci ze strany ordináře, územního preláta nebo opata z cizí země na území Slovenské republiky a samostatné slovenské církevní provincie (její západní nebo východní části latinského obřadu a/nebo Prešovské řeckokatolické metropolie sui iuris). Podle CIC/1983, kán. 370 platí, že „územní opatství je určitý podíl Božího lidu, územně ohraničený, který pro zvláštní okolnosti je svěřen do péče některému (...) opatu, jenž ho na způsob diecézního biskupa řídí jakožto jeho vlastní pastýř." To je, samozřejmě, i př́pad Pannonhalmského opatství, jehož opatem je tatáž osoba, která stojí v čele Mad’arské benediktinské kongregace a současně se považuje za „nejvyššího představeného Řádu svatého Benedikta se sídlem v Komárně."

Navzdory vydání konstituce Praescriptionum sacrosancti, díky níž se měly všechny spory týkající se územní církevní jurisdikce, včetně „pannonhalmské otázky“ považovat za uzavřené, po pádu totalitního reži-

21 Damián NĚMEC, „Některé aspekty konkordátních smluv obecně a konkordátních smluv s postkomunistickými zeměmi speciálně, “ Revue církevního práva 15, č. 2 (2009): 96-97. K způsobům konce platnosti mezinárodní smlouvy viz např. Ján Azud, Základy medzinárodného práva, Banská Bystrica: Fakulta politických vied a medzinárodných vztahov Univerzity Mateja Bela v Banskej Bystrici, 2001, s. 261-262.

22 Jiří Rajmund Tretera - Záboj Horák, Konfesní právo, Praha: Leges, 2015, s. 368, kurzíva v orig. O modu vivendi viz blíže Drahomír SucháNeK, „Modus vivendi,“ Revue církevního práva 8, č. 3 (2002): 205-224.

23 Viz např. seznam subjektů ženských řeholí se sídlem provinciálního vedení mimo území Slovenska: http://www.kvpzr.sk/adresar/. Za závislý je považován např. i premonstrátský řeholní dům v Holíči (závislý na pražském Strahovském klášteře), viz http:// www.kvrp.sk/adresar/. 
mu v roce 1989 „došlo k znovuotevření starého sporu z důvodu nerespektování pravidel (ze strany Mad’arské benediktinské kongregace, doplnil autor), což si vyžádalo poslední zásah Svatého stolce vydáním (...) dekretu (z 13. listopadu 2015, doplnil autor),“ jak se uvádí v oficiálním stanovisku Trnavské arcidiecéze datovaném po veřejném oznámení o vydání tohoto dekretu. ${ }^{24}$

\section{Dekret Posvátné kongregace pro Řeholníky Ze 40. Let}

Již $\mathrm{v}$ roce 1935 , tedy $\mathrm{v}$ době platnosti modu vivendi, vyjádřil Státní sekretariát Svatého stolce jakožto kompetentní orgán svojí nótou č. 1576/35 ze 14. května, aby byl majetek (!) Pannonhalmského opatství nacházející se na území Československé republiky odevzdán do správy zástupci Svatého stolce, za něhož byl ustanoven tehdejší trnavský apoštolský administrátor, biskup mons. Pavol Jantausch. Jednalo se o přirozené úsilí Svatého stolce napravit všechny nesrovnalosti týkající se této otázky. Vláda ČSR na tuto nótu reagovala pozitivně a prostrednictvím svého velvyslanectví v roce 1937 požádala, aby byl tento majetek ponechán mons. Jantauschovi až do doby, kdy se uzavře a naplní dohoda mezi ČSR a Svatým stolcem o všech otázkách dotýkajících se majetků slovenských diecézí. Pavol Jantausch svým dopisem z roku 1938 tehdejšímu státnímu sekretáři a pozdějšímu papeži, kardinálu Pacellimu, potvrdil, že církevní majetky (!) Pannonhalmského opatství nacházející se na území ČSR byly úspěšně odevzdány do jeho správy.

V roce 1947 byl Posvátnou kongregací pro řeholníky, předchůdkyní dnešní již výše zmiňované Kongregace pro instituty zasvěceného života a společnosti apoštolského života, vydán dekret č. 2008/1946. Ten se týkal pouze řeholního domu v Komárně, ale ne už jiných někdejších „enkláv“ Pannonhalmského opatství, tj. území farností Trávnik a Diakovce. Řeholní dům v Komárně byl na základě zmíněného dekretu vyňat $\mathrm{z}$ jurisdikce pannonhalmského arciopata a byl označen za dům sui iuris, což předpokládalo ustavení vlastního představeného. To se však nestalo a posvátná kongregace určila administrátorem domu předsedu

24 Srov. „Rozhovor na tému: Svätá stolica zrušila Rád sv. Benedikta v Komárne“ (s mluvčím Trnavské arcidiecéze Dušanem Kolenčíkem), http://www.abu.sk/archiv/spravy/ rozhovor-na-temu-svata-stolica-zrusila-rad-sv-benedikta-v-komarne [zveřejněno 14. 12. 2015, cit. 22. 12. 2015]. 
Slovanské benediktinské kongregace sv. Vojtěcha. Jím nebyl předseda Mad’arské benediktinské kongregace, kterým byl v té době pannonhalmský arciopat Krizosztom Kelemen, O.S.B. († 1950), jehož nástupcem je současný arciopat mons. Várszegi, který se považuje za hlavního představeného řeholního domu v Komárně. Naopak dekret byl adresován opatu "Slovanské kongregace Řádu sv. Benedikta, " kterým byl v letech 1946-1969 Maura Verzich, O.S.B. († 1992). Ten dekret předal na apoštolské nunciatuře v Praze. Záležitost řeholního domu v Komárně spadala pod zmíněný modus vivendi a byla tudíž v kompetenci Státního sekretariátu, nikoli Posvátné kongregace pro řeholníky. Současně měla být záležitost ex ante řešena i s trnavským apoštolským administrátorem, na jehož území sporný dům ležel, což se nestalo.

V př́padě "Slovanské kongregace Řádu sv. Benedikta“ se nejedná o Mad’arskou kongregaci benediktinů (byla založena jako třetí nejstarší v roce 1514), ale o Slovanskou benediktinskou kongregaci sv. Vojtěcha, která vznikla v roce 1945 po 2. světové válce, do níž aktuálně patří tyto kláštery: Benediktinské arciopatství sv. Vojtěcha a sv. Markéty v Praze Břevnově, Benediktinské opatství sv. Václava v Broumově (od roku 1999 jejejich převorem-administrátorem Prokop Siostrzonek, O.S.B.), Benediktinské opatství sv. Petra a Pavla v Rajhradě (převorem-administrátorem je Augustin Gazda, O.S.B.), Benediktinské opatství Panny Marie a sv. Jeronýma - Emauzy (Praha; převorem-administrátorem je Edmund Wagenhofer, O.S.B., emeritní arciopat ze Salcburku), Převorství sv. Cyrila a Metoděje Maribor (Slovinsko), Převorství sv. Kosmy a Damiána Ćokovac (Chorvatsko). ${ }^{25}$ Tato kongregace byla na základě stanov schválených na generální kapitule v roce 2003 definována jako sborová právnická osoba, tedy svazek právně samostatných klášterů ve slovanských zemích, která je členem Benediktinské konfederace.

Při generální kapitule Slovanské benediktinské kongregace sv. Vojtěcha v roce 2001 jmenoval opat-primas Konfederace benediktinských kongregací Notker Wolf, O.S.B., sídlící v Římě (v této funkci je od roku 2000 až doposud; znovuzvolený v letech 2008 a 2012) svým delegátem $\mathrm{v}$ této kongregaci arciopata mons. Imre Asztrika Várszegiho, O.S.B., z Pannonhalmského opatství.

Na tomto místě je vhodné připomenout, že benediktinská řehole nemá generálního představeného, ale jednotlivé autonomní kongregace

25 Ordo Sancti Benedicti, „Slovanská benediktinská kongregace sv. Vojtěcha,“ http://benediktini.cz/kongregace.html [datum zveřejnění neznámý, cit. 22. 12. 2015]. 
jsou podle rozhodnutí papeže Lva XIII. z 12. července 1893 sdruženy do Benediktinské konfederace (lat. Confeederatio Benedictina Ordinis Sancti Benedicti), v jejímž čele stojí opat-primas (lat. Abbas Primas). ${ }^{26}$ Jednotlivé řeholní domy jsou sdruženy do národních, resp. nadnárodních kongregací, což je, samozřejmě, i př́ípad Mad’arské benediktinské kongregace a Slovanské benediktinské kongregace sv. Vojtěcha. Každá kongregace si volí svého předsedajícího opata.

V každém př́ipadě se na sporný řeholní dům v Komárně i v roce dobře míněného obnovení jeho řádné činnosti, tedy v roce 1990, nahlíželo jako na dům závislý, konkrétně závislý na Pannonhalmském opatství. I z tohoto důvodu byl vznesen první požadavek mons. Sokola (viz výše).

Tuto skutečnost, tj. faktickou závislost tohoto domu na Pannonhalmském opatství, stvrzuje i Konstituce Kongregace mad’arských benediktinů z roku 1995. V ní se uvádí, že k pannonhalmskému nezávislému klášteru přísluší kromě závislých klášterů v Budapešti, Györi a Tihány-i i závislý klášter v Komárně. A to navzdory apoštolské konstituci Praescriptionum sacrosancti z roku 1977. Zmíněná mad’arská konstituce byla dokonce v září 1996 schválena i Kongregací pro instituty zasvěceného života a společnosti apoštolského života, čímž byla fakticky ukončena platnost předchozího dekretu Posvátné kongregace pro řeholníky č. 2008/1946. Tak Kongregace mad’arských benediktinů i Apoštolský stolec tedy pohlížely na dům v Komárně jako na závislý na Pannonhalmském opatství.

I když se tedy současný arciopat, mons. Várszegi, O.S.B., odvolával v rámci sporu s Trnavskou arcidiecézí na dekret Posvátné kongregace řeholníků č. 2008/1946 z roku 1947, aby tak obhájil svůj nárok na dům v Komárně a považoval jeho obnovení v roce 1990 pouze za pokračování jeho činnosti, přehlížel skutečnost, že (a) dům byl Svatým stolcem vyčleněn ze svazku Kongregace mad’arských benediktinů a přičleněn ke Kongregaci sv. Adalberta (Vojtěcha), tedy ke Slovanské benediktinské kongregaci sv. Vojtěcha, čímž byl de iure vyňat z jurisdikce Pannonhalmského opatství, (b) je i nadále - paradoxně - považován za závislý dům, a to samotnou Kongregací mad’arských benediktinů i Apoštolským stolcem díky schválení konstituce z roku 1995 dne 3. září 1996. ${ }^{27}$

26 Viz Lev XIII., „Nuperrimæ Constitutiones Benedictorum "Summum semper', Acta Sanctae Sedis 26 (1893): 371-374.

27 „The Hungarian Benedictine Congregation (Congregatio Hungarica Sancti Benedicti) is a union of autonomous monasteries and their dependent houses, immediately depen- 


\section{ZÁMEČeK v Rusovcích}

Spor o dům v Komárně není jediným, který vedli mad’arští benediktini ohledně majetků na území Slovenské republiky. ${ }^{28} \mathrm{~V}$ roce 2012 prohráli soudní spor (probíhající od dubna 2007) na Krajském soudu v Bratislavě, kde se domáhali vrácení nemovitostí v katastrálních územích Rusovce, Čunovo, Jarovce a Podunajské Biskupice. Soud nakonec zamítl i jejich odvolání.

V samostatném a delším soudním řízení požadovali navrácení zámečku v Rusovcích, který jim měl být odkázán princeznou Štefánií Lónyayovou, ${ }^{29}$ manželkou knížete Elemíre Lónyaye, někdejší manželkou korunního prince Rudolfa Habsburského. Šlechtický pár se do zámečku nastěhoval v roce 1906 poté, co jej koupil po smrti předchozí majitelky, hraběnky Laury Henckel von Donnersmarck. Štefánie dožila v roce 1945 v klášteře benediktinů v Pannonhalmě a mad’arští benediktini spravují její jmění a soukromý archiv. Negativní dojem, jaký soudní spor zanechal ve slovenské veřejnosti, vedl dokonce v říjnu 2012 slovenské benediktiny sídlící v Klášteře Proměnění Páně v Samporu k oficiálnímu prohlášení, že „nemají nic společného“ s Mad’arskou benediktinskou kongregací. ${ }^{30}$

dent houses (and) monasteries whose legal rights are currently suspended due to exterior circumstances, parishes and chapels of its territorial abbey (...). As a juridic (sic!) person, capable of acquiring, possessing, administering and alienating temporal goods (CIC 634, § 1), it incorporates the following: a) Independent monasteries of monks of the Congregation: Saint Marton's Archabbey, Pannonhalma, Hungary; Dependent Houses: Budapest, Györ, Tihany (Hungary), Komárom (Slovakia)..." The Constitution of the Hungarian Benedictine Congregation, 1995, s. 23; archiv autora, kurzíva autor.

28 Budiž na okraj poznamenáno, že dne 24. 2. 1998 byla uzavřena darovací smlouva (DZ 11/98 - BU), jejímiž smluvními stranami byly „Rímskokatolícka cirkev, Biskupstvo Banská Bystrica“ se sídlem v Banské Bystrici a "Rád svätého Benedikta“ se sídlem v Komárně. Předmětem smlouvy bylo darování několika parcel a lesních porostů v katastrálních územích Vieska pri Žiari nad Hronom, Lehôtka pod Brehmi, Horné Opatovce a Ladomer v celkové výši 37809000 tehdejších slovenských korun. Dárcem byla Banskobystrická diecéze.

29 Celým jménem Štefánie Klotilda Louisa Hermína Marie Charlotta (21. 5. 1864-23. 8. 1945), známá i jako „Štefánie Belgická.“ Viz např. Stephanie LónYAy, Měla jsem být císařovnou: Vzpomínky poslední rakousko-uherské korunní princezny, Praha: Dr. Ot. Štorch-Marien, 1936 (v orig. Stephanie Von Belgien, Fürstin Von Lonyay, Ich sollte Kaiserin werden: Lebenserinnerungen der letzten Kronprinzessin von Österreich-Ungarn, Lipsko: Koehler\&Amelang, 1935), Irmgard Schielová, Stefanie: Životní osudy vdovy po následníkovi rakouského trưnu, Praha: Brána, 2002.

30 Tlačová kancelária KBS, „Stanovisko slovenských benediktínov o kauze ,Kaštiel” v Rusovciach'," https://www.tkkbs.sk/view.php?cisloclanku=20121029026 [zveřejněné 29. 
Kongregace mad’arských benediktinů v prosinci 1994 požádala o vydání nemovitosti zámečku v Rusovcích, ale neuvedla všechny zákonné náležitosti, a proto stát shledal tuto žádost jako nulitní. Se svou stížností neuspěla kongregace v roce 2005 na Okresním soudu Bratislava 5 a později (2006) ani na Krajském soudu v Bratislavě, na Ústavním soudu SR (2008) a v roce 2012 ani na Nejvyšším soudu SR. Tento svým usnesením z 27. 9.2012 (č. 1 Cdo 116/2011) rozhodl o odmítnutí dovolání navrhovatele. Tím de facto potvrdil, že zámeček je ve vlastnictví Úřadu vlády SR. Spor Mad’arská benediktinská kongregace přenesla později v podobě petice č. 1002/2013 z 26. 6. 2013 i do Evropského parlamentu (EP) a na Evropský soud pro lidská práva ve Štrasburku. Zmíněnou petici předložil osobně Asztrik Várszegi, O.S.B., jakožto státní občan Mad’arska. Předkladatel „vyjádřil obavy, že až bude v roce 2016 Slovensko předsedat EU, nepř́mo potvrdí postavení Slovenska ve vztahu k benediktinskému opatství v Pannonhalmě.“ Předkladatel peticí požádal „o pomoc a zachování dobrého jména EU. “31 Na žádost poslanců EP (Victor Boştinaru, Jaroslav Paška, Nikolaos Salavrakos) byla petice vyhlášena Výborem EP pro petice za nepř́ípustnou. Následně se mad’arští benediktini (Magyar Bencés Kongregáció Pannonhalmi Főapátság) obrátili se žalobou proti EP na V̌̌eobecný soud EU. Žalobce ve své žalobě z 13. 6. 2014 (Věc T-453/14) žádal, aby soud „zrušil rozhodnutí Petičního výboru EP z 16. dubna 2014 o odložení petice podané ve věci zámeček Lónyayovců v Rusovcích (Slovensko), nařídil Petičnímu výboru EP petici přezkoumat a přijmout všechna opatření požadovaná právními předpisy, zavázal EP k úhradě nákladů ř́zení. “32

Ani tato aktivita Pannonhalmského opatství nebyla korunována úspěchem, nebot’ 6. komora Soudního dvora EU v Lucemburku se ve svém rozhodnutí z 10. 9. 2015 usnesla, že: 1) odvolání mad’arské strany se zamítá, 2) Mad’arská kongregace benediktinů je povinna uhradit náklady řízení, 3) není třeba rozhodovat o žádosti o intervenci Slovenské

10. 2012, cit. 26. 12. 2015].

31 Petícia 1002/2013, ktorú predkladá Varszegi Asztrik, mad’arský štátny občan, o reštitúcii kaštiel'a rodiny Lónyay v Rusovciach, Slovensko, https://petiportpp.secure.europarl.europa.eu/petitions/sk/main [datum zveřejnění neznámé, cit. 26. 12. 2015].

Žaloba podaná 13. júna 2014 - Pannonhalmi Főapátság/Parlament, http://eur-lex.europa.eu/legal-content/SK/TXT/?uri=CELEX\%3A62014TN0453 [zveřejněné 13. 6. 2014, cit. 26. 12. 2015]. 
republiky a Mad’arska. ${ }^{33}$ Doposud tedy všechny soudní orgány vnitrostátní i evropské úrovně potvrdily vlastnické právo Slovenské republiky ve věci zámečku v Rusovcích. Dosavadní situace týkající se řeholního domu v Komárně není nepodobná vývoji kauzy rusoveckého zámečku s tím rozdílem, že se odehrává (a zjevně i nadále bude odehrávat) na půdě dikasterií Římské kurie.

Dne 5. dubna 2016 bylo na facebookových stránkách slovenského poslance EP a místopředsedy Petičního výboru EP Pála Csákyho zveřejněno video $\mathrm{v}$ mad’arském jazyce ${ }^{34} \mathrm{z}$ jeho diskuse $\mathrm{s}$ arciopatem mons. Várszegim a páterem Dr. Juhászem-Laczikem Albinem ohledně zámečku v Rusovcích. Během debaty se diskutující snaží vysvětlit, že nevydání zámečku benediktinům je anomálie, jelikož na základě testamentu princezny Štefánie Lónyayové mad’arští benediktini v minulosti nabyli majetek Zeiselhof v rakouském Burgenlandu. Testament podle nich obsahuje poznámku, že kdyby Pannonhalmské opatství nebylo schopno nabýt rusovecký zámeček, mělo by být dědictví předáno benediktinskému Opatství sv. Anzelma v Římě. Současně diskutující reprezentanti opatství informují, že aktuálně v komárenském řeholním domě nepůsobí řeholníci řádu, čímž nepřímo přiznávají, že za 26 let od vydání dekretu mons. Sokola nebyly splněny podmínky v něm uvedené. Tentýž den se uskutečnil na půdě EP i veřejný kulatý stůl na téma „Nevyřešené restituční otázky v postkomunistických zemích “35 za účasti poslance EP P. Csákyho a zástupců Pannonhalmského opatství.

\section{ZÁvĚr}

Jelikož nebylo možné vzhledem k existujícím propojením na osobu pannonhalmského arciopata řeholní dům ve městě Komárně nepovažovat

33 Document du travail, Ordonnance du Tribunal, 10 septembre 2015, http://curia.europa.eu/juris/document/document.jsf;jsessionid=9ea7d2dc30dd3977e161aed6409f9e5bab163229509b.e34KaxiLc3qMb40Rch0SaxuRc3n0?text=\&docid=168082\&pageInde$\mathrm{x}=0$ \&doclang=FR\&mode=lst\&dir $=\& o c c=$ first\&part $=1 \& c i d=238916$ [zveřejněné 10.9 . 2015, cit. 27. 12. 2015].

34 Beszélgetés a pannonhalmi bencésekkel, https://www.facebook.com/csakypal/videos/554369748073629/ [zveřejněné 5. 4. 2016, cit. 20. 4. 2016].

35 Az oroszvári bencés tulajdonról is tárgyaltak az Európai Parlamentben, http://felvidek. ma/2016/04/az-oroszvari-bences-tulajdonrol-is-targyaltak-az-europai-parlamentben/ [zveřejněné 5. 4. 2016, cit. 20. 4. 2016]. 
za dům závislý na Pannonhalmském opatství a klášter nejevil známky reálného řeholního života, bylo odebrání souhlasu k pastorační činnosti ze strany ordináře Trnavské arcidiecéze, mons. Orosche, založené na dekretu jeho předchůdce mons. Sokola z roku 1990, zcela oprávněné a v souladu s kanonickým právem. Dekret mons. Sokola přitom vycházel ze zásad modu vivendi z roku 1928, zejména ze zásady týkající se principu svrchovanosti jurisdikce ordinářù, která je plně v souladu s trianonskou mírovou smlouvou i apoštolskou konstitucí Praescriptionum sacrosancti a ze zásad II. vatikánského koncilu ve vztahu církev-stát, tj. zásady náboženské svobody, spolupráce, autonomie a nezávislosti církve.

Pokračování dosavadního faktického stavu mohlo vést nejenom $\mathrm{k}$ porušování kanonického práva, ke zhoršení pověsti katolické církve v SR, zpochybňování zmíněné apoštolské konstituce z r. 1977, ale i k porušování mezinárodní smlouvy mezi Slovenskou republikou a Apoštolským stolcem z roku 2000 (zákon č. 326/2001 Z. z.), a to v případě výkladu in extenso čl. 3, odst. 3 této smlouvy. Svatý stolec totiž dodržuje a garantuje soulad diecézních hranic se státními hranicemi SR, ale nebyl by schopen zajistit plnou jurisdikci biskupů nad nimi (v př́padě Trnavské arcidiecéze) a zavdal by základ právní argumentace u soudních sporů (existujících nebo budoucích) ve věci převodů majetků slovenských církevních územně-správních celků na Mad’arskou benediktinskou kongregaci, v jejímž jménu vystupuje její předsedající opat, mons. Várszegi, O.S.B., pannonhalmský arciopat a současně „,nejvyšší představený Řádu svatého Benedikta se sídlem v Komárně, " jehož územní jurisdikce jakožto ordináře je na území Mad’arska, tedy ne Trnavské arcidiecéze, kde je jediným ordinářem mons. Ján Orosch. Takovéto jednání poškozující dobré jméno Apoštolského stolce by si př́slušné autority, dbající na diskrétnost diplomacie a serióznost $\mathrm{v}$ jednání se státy, $\mathrm{v}$ žádném př́padě nedovolily. ${ }^{36}$ Navíc, opakované vystupování mons. Várszegiho, O.S.B., $\mathrm{v}$ trojité roli momentálně zamlžuje a znemožňuje jasné a řádné rozlišení toho, zda je třeba podřízenost benediktinského domu v Komárně považovat za podřízenost vyššímu řeholnímu představenému, anebo pan-

36 O diplomacii Svatého stolce a jeho zásadách viz více např. Marián SEKERÁK, „PÔsobenie Svätej stolice v medzinárodnej politike a jej diplomatická služba," Politologická revue 18, č. 1 (2013): 58-86; týž, „Dávid a Goliáš: Spolu alebo proti sebe? Bilaterálne vztahy Svätej stolice a USA v kontexte medzinárodnej politiky," Acta Fakulty filozofické Západočeské univerzity v Plzni 6, č. 3 (2014): 55-84. 
nonhalmskému ordináři, jehož jurisdikce, jak již bylo zmíněno, není na území Slovenské republiky.

I z tohoto důvodu Kongregace pro instituty zasvěceného života a společnosti apoštolského života rozhodla ve prospěch trnavského arcibiskupa, čímž přispěla i k ukončení (alespoň do jisté doby) narušování "dynamismu jednoty" mezi místními církvemi, po němž volal Joseph Ratzinger ve výše citovaném výroku. Jak se totiž uvádí v „Dopisu biskupům katolické církve o některých aspektech církve chápané jako společenství“ (1992), jenž byl vydán Kongregací pro nauku víry, „budování a střežení této jednoty (...) je úkolem každého v církvi, protože všichni jsou povoláni budovat ji a chránit ji každý den, a to především prostředky lásky, která je ,poutem dokonalosti‘." ${ }^{\text {37 }}$

Po náročném a složitém prokazování zmíněných skutečností a nesrovnalostí se rozhodnutí Kongregace pro instituty zasvěceného života a společnosti apoštolského života potvrzující krok mons. Orosche jeví ze slovenského pohledu jako úleva. Na druhé straně řádné uplatnění rekursu ze strany mons. Várszegiho, O.S.B., na základě kán. 1735 a násl. CIC/1983 by mohl mít za následek nejenom pozastavení účinnosti rozhodnutí dekretu kongregace Prot. N. 1742/1990, ale i vynesení nového nebo opravného rozhodnutí. Tento krok veřejně ohlásil mons. Várszegi, O.S.B., v slovenských médiích, když řekl, že „کrád je (...) nucen využít opravné prostředky před př́slušnými orgány Svatého stolce, které mu kanonické právo přiznává, a to způsobem a ve lhưtách stanovených kanonickým právem, včetně odkladu vykonatelnosti dekretu. “38 Jiný jeho veřejný nebo soukromý výrok ohledně dalšího postupu není autorovi tohoto textu znám. V každém případě, podle kán. 1734 CIC/1983 musí žadatel o rekurs podat svou žádost původci dekretu „V zahlazující lhůtě 10 započitatelných dnů ode dne, kdy ve shodě s předpisy práva byl dekret dotyčnému oznámen."

Zajímavým je v této souvislosti dopis italských právních zástupců Pannonhalmského opatství (jimiž jsou Carlo Gullo a Alessia Gullo) adresovaný Kongregaci pro instituty zasvěceného života a společnosti apo-

37 Congregatio pro doctrina fidei, „Litteræ ad Catholicæ Ecclesiæ episcopos de aliquibus aspectibus Ecclesiæ prout est communio," Acta Apostolicae Sedis 85, č. 9 (1993): 847, § 15. 
štolského života $\mathrm{z}$ března $2016^{39} \mathrm{~s}$ odůvodněním údajného porušení již výše zmíněného kán. 616, § 1 CIC/1983, podle něhož ruší řeholní dům nejvyšší představený řehole po konzultaci s diecézním biskupem. Autoři dopisu přímo uznávají, že dům je závislý na Pannonhalmě (uvádějí přitom i rưzné historické okolnosti). Na tomto místě ale uvádějí čtenáre v omyl, když píší, že arcibiskup zrušil dům v Komárně (v ital. orig. sopprimere la casa Benedettini di Komarno), což není pravda, jelikož mons. Orosch odňal souhlas na pastorační působení benediktinů, ale dům jako takový nezrušil. Tuto formulaci používal mons. Várszegi již ve svém dopisu mons. Carballovi, sekretáŕi Kongregace pro instituty zasvěceného života a společnosti apoštolského života, ze dne 10. 12. 2014, který byl již $\mathrm{v}$ tomto textu zmíněn. Závěr tohoto dopisu právních zástupců je výčtem požadavků, co by měla kongregace udělat, aby změnila své dřívější rozhodnutí. ${ }^{40}$

Jinou možností, kterou mohl mons. Várszegi, O.S.B., uplatnit u Svatého stolce, bylo obrátit se na Nejvyšší tribunál apoštolské signatury, a to v souladu s apoštolskou konstitucí Jana Pavla II. Pastor bonus. Tento tribunál totiž podle čl. 123, § 1 zmíněné konstituce „rozhoduje o stížnostech, které jsou podány $\mathrm{v}$ užitečné lhůtě třiceti dnů a směřují proti jednotlivým správním aktům, které byly vydány nebo schváleny dikasteriemi Rímské kurie, a to tehdy, když je otázkou, zda napadený akt, at’ již byl vydán nebo vykonán, porušil nějaký zákon."

Jelikož se celý proces odehrává na interním fóru a prozatím kromě výše zmíněných mediálních výstupů mons. Várszegiho, O.S.B., ze začátku dubna 2016 na půdě EP nebyly doposud zveřejněny žádné doplňující informace ani rozhodnutí Svatého stolce v této věci, není možné určit, jak reagovala Kongregace pro instituty zasvěceného života a společnosti apoštolského života na dopis právních zástupců Pannonhalmského opatství. Autor předkládané studie v této věci interpeloval Tiskové oddělení Trnavské arcidiecéze, které mu sdělilo, že k polovině ř́jina 2016

39 Dopis právních zástupců (Carlo Gullo a Alessia Gullo) ze dne 8. 3. 2016, jehož adresátem je mons. João Braz kardinál De Aviz, prefekt Kongregace pro instituty zasvěceného života a společnosti apoštolského života. Autorovi není známo, zda byl skutečně odeslán a doručen adresátovi.

40 V italském originálu: „1. Che sia revocato, perché illegittimo (in procedendo et/vel in decernendo) e/o inopportuno, il decreto del 13.11.2015; 2. Sia ingiunto all' Arcivescovo di Trnava di ripristinare lo status quo ante canonico, civile e fattuale; 3 . Sia permesso, giuridicamente e di fatto, alla Congregazione Benedettina Ungherese di fare i lavori necessari per ricostituire la Comunità di Komarno." 
nedisponovalo žádnou takovouto informací. Rovněž byl dne 10. dubna 2016 elektronickou poštou kontaktován mons. Várszegi, O.S.B., který dne 1. 6. 2016 laskavě poskytl autorovi kromě některých svých výše zmiňovaných dopisů i dopis právních zástupců z března 2016.

Bez ohledu na další vývoj této konkrétní kauzy se nic nemění na možnosti dalšího pokračování a rozvoje řeholního života na Slovensku, včetně benediktinů. $\mathrm{V}$ každém případě $\mathrm{k}$ „lepšímu docenění platného přínosu všech řeholníků v pastorační činnosti“" vyzval slovenské biskupy během jejich návštěvy ad limina apostolorum v Římě v listopadu 2015 i papež František. ${ }^{41}$

\section{Notes on Jurisdictional and Property Conflict Between the Territorial Abbey of St. Martin on Pannonian Mountain and the Trnava Archdiocese}

Keywords: Benedictine Order; Slovak Republic; Hungary; Congregation for Institutes of Consecrated Life and Societies of Apostolic Life; Holy See

Abstract: In the article I explain certain aspects of the longstanding jurisdictional and property conflict between the Territorial Abbey of St. Martin on Pannonian Mountain (Hungary) and the Trnava Archdiocese (Slovak Republic). Based on an analysis of existing historical documents it is justified that the withdrawal of consent to the pastoral action of the Hungarian Benedictine monastic House in Komárno by Archbishop Ján Orosch was fully in accordance with canon law. The main reason was that the House in Komárno was not an independent house sui juris, and proper religious life was not practised there. This fact was confirmed by a decree of the Congregation for Institutes of Consecrated Life and Societies of Apostolic Life in November 2015.

PhDr. Marián Sekerák

Institut politologických studií

Fakulta sociálních věd UK

U Kř́žze 8

15800 Praha 5 - Jinonice

marian.sekerak@gmail.com

41 FrantišeK, „Príhovor pápeža Františka slovenským biskupom - ad limina,“ http:// sk.radiovaticana.va/news/2015/11/12/pr\%C3\%ADhovoru_p\%C3\%A1pe\%C5\%BEa_ franti\%C5\%A1ka_slovensk\%C3\%BDm_biskupom_-_\%E2\%80\%9Ead_limina$\% \mathrm{E} 2 \% 80 \% 9 \mathrm{C} / 1186273$ [zveřejněné 12.11 .2015 , cit. 24. 12. 2015]. 